\title{
Why the Armenian Genocide Lives in Me
}

\author{
Barbara Erysian \\ Department of Mathematics, Sierra College, Rocklin, CA 95677, USA; berysian@sierracollege.edu
}

Received: 6 September 2018; Accepted: 14 November 2018; Published: 21 November 2018

Abstract: Little has been taught about the Armenian Genocide of 1915 when approximately 1.5 million Armenians were brutally slaughtered. Moreover, the events are still being denied today. Community College Math Professor Barbara Erysian, an unlikely candidate to tell the story, carries the memories and sorrow of her people. She has dedicated herself to telling the story of how her grandmother survived the genocide. The story, repeatedly told to her as a child, is very much a part of her identity. Her essay describes some of the terrors of 1915. She believes the memory and pain of the Armenian Genocide must be told so that these crimes are never forgotten.

Keywords: Armenian; genocide; 1915; human rights violation; Christianity; Holocaust

I remember her vividly. She was a tiny woman who could look me straight into the eyes. I imagine that she stood about 5 feet tall. She had waist long silver hair. As a child, I would watch in amazement each morning as she would braid and then carefully twist and turn and pin her hair into a neat bun on the top of her head. She loved to cook Armenian food and everyone loved to eat it. Throughout the day, I could often hear her say, "thank you Jesus."

But it was not her hair or her sayings that became part of me. It was the story that she repeated so often ... so clearly and so passionately. Every day I visited her, and several times a day after she got Alzheimer's, she would tell me how she survived the Armenian Genocide. Since I was only a child, I could not really understand what she was saying or how it could have been possible. How could such terrible things have happened to this petite, loving woman that I called "Grandma Alice"?

The treacherous story with the unexpected ending was always the same. Her father was taken in the dead of the night. All she knew about what happened to him was that he was buried alive in the desert. I later determined this would have been the Syrian Desert because that is where approximately 1.5 million Armenians would have died after being forced to march in the hot, burning sun with no food or water. She would then tell me how she and her little brother were taken to an orphanage. She would have been 14-years-old and her brother would have been 6-years-old in 1915.

I always wondered why she never mentioned what happened to her mother. Didn't she know? Or, why wouldn't she tell me? When the Turkish Government issued an order to kill every Armenian, young or old, without mercy - they did worse. I believe that what was done to her mother was so horrific that she would not or could not find the words to tell me. I believe that my great grandmother was possibly raped or sliced or burned or hung or poisoned or drowned or any combination of these or worse. During those days, the Armenians were shown no mercy. My grandmother witnessed a baby being sliced from its mother's womb and hot oil being poured down a man's throat. And the stories of wide scale torture and slaughter are Barbaric and horrific. The accounts of diplomats in the region pleading for help went unanswered. The letters from Armenians seeking help and relief are so fraught with sorrow that one must turn away. The murderous rampage was nothing short of barbarism and this massacre set a precedent for the Jewish Holocaust in the 1930's.

In the orphanage, my grandmother and her brother nearly starved to death. Her assigned job was to wash the dead bodies. And, after the work was done she could eat. The bread was made 
out of corn cobs. What she did tell me was that after every meal she would walk the entire length of every table. She would start with only one bread crumb. And from there, she would gather two and then three crumbs and soon she would have a wad of dough. She would feed this small wad of dough to her young brother "to keep him alive." When telling me the story, she would then place imaginary wad dough into my hand and implore me, "Tell your children. Tell your children's children ... Never forget."

I have lived with this story for forty years. As a child, I did not truly understand what she had experienced. I did not learn to speak Armenian unless one considers counting to ten. I learned to cook a few Armenian dishes and wore a traditional Armenian dress to a junior high school function. When my children were in elementary school, I encouraged them to do projects on Armenia. And so, they did Armenian cooking projects (Baklava—of course) and costume projects and music projects.

But five years ago, as I was watching the television, it seemed as though I was watching the story unfold again. Isis was slaughtering the infidels in the Middle East-needlessly, ferociously, viciously and in a barbaric fashion once again ... just like 100 years ago. I began researching the Armenian Genocide and discovered that not only were Armenians slaughtered but also Greeks, Assyrians, Jews, Atheists, and anyone else who was non-Muslim. They were drowned in the Black Sea, buried alive in the Syrian Desert and slaughtered everywhere in-between. Could it be that history was repeating itself?

As I watched the tragic stories unfold on television, I realized that I had carried this story inside myself for 40 years. It was as much a part of me as her. As she placed that wad of dough into my hand she placed not only the story, but the memories of the suffering, of the pain and of the injustice. She had laid her story upon my heart and I took it upon myself to tell not only her story but the story of the Armenian people that were needlessly slaughtered in 1915. I contemplated writing a book but soon realized that in order to reach the widest possible audience I would need to make a movie. As naïve as that sounds I set out on this passion project. I began researching how to write a screenplay and five years later, I've created a short film paying homage to my grandmother in hopes that someday I will make a feature film akin to Schlinder's List. My goal is to make a film that everyone will see and discuss and learn from so that the Armenian Genocide will not be buried in the history books nor be allowed to be denied.

Researching the Armenian Genocide over the past several years has taught me several things. First, that the wounds are still very real and very painful for the Armenian people. Every 24 April, Genocide Day is recognized throughout Armenian communities all over the world. This is a day that Armenians gather to grieve and remember the horrible events of the past. The commemorators around the world join together to pray, sing, dance, and speak about the massacre of their ancestors. The tears and passion lives on in the lives and hearts of the children and grandchildren.

Secondly, I learned that during the genocide there were ambassadors and missionaries and diplomats in Armenia who were pleading for help. Many, many articles were published in the New York Times giving accounts of the horrific events in Armenia. But, the desperate cries for help, assistance and relief were answered with silence.

For some Armenians, the pain is so deep they cannot talk about it. The stories they have heard lives deep within them and will be passed to their children in deep and subtle ways. It is not only what one speaks about that is transferred but also the silence. One of the worst parts of the Armenian Genocide, that I believe prevents any real healing, is that the current Turkish Government fails to take responsibility for these events. The fact that the Armenian Genocide is vehemently denied by those who know what happened continues to perpetrate the pain and suffering.

The dedication on my film reads, "To my Grandmother Alice and all those who perished and all those who survived." In creating the movie and connecting with other Armenians, I realized that the pain we feel is deep.

The title of my film, "Who Will Remember", is taken from the quote from Adolf Hitler who stated, "Who will remember the annihilation of the Armenians?" He spoke these haunting words 
prior to invading Poland and slaughtering thousands of Jews. It is my hope and prayer that WE WILL REMEMBER. I believe that we must.

Funding: This research received no external funding.

Conflicts of Interest: The author declares no conflicts of interest. article distributed under the terms and conditions of the Creative Commons Attribution (CC BY) license (http://creativecommons.org/licenses/by/4.0/). 